\title{
In memoriam: Frank Ambrose Beach
}

\author{
BENJAMIN D. SACHS \\ The University of Connecticut, Storrs, Connecticut
}

\begin{abstract}
Of course I shall never accomplish all of [my] objectives ..., but that is unimportant. What counts is to have aims, to be able to work toward them, and to experience the satisfaction of at least believing that progress is being made. I do not want to cross the finish line of this race-not ever-but I do hope I will be able to keep running at my own pace until I drop out still in full stride. It's been one hell of a good race up to this point.
\end{abstract}

Frank Ambrose Beach was born in Emporia, Kansas, on April 13, 1911, and he died of congestive heart failure in Berkeley, California, on June 15, 1988. In the intervening years he contributed immeasurably to the growth and differentiation of psychobiology through his research, his teaching, and his conceptual and methodological insights.

But teaching English, not psychology, was Frank's initial goal. He received his BS (1933, in education) and MS (1934, in psychology) from Emporia State Teachers' College. Frank did teach English in high school for two years (and with more or less success to his graduate students for many years after!), but that was in an interlude during his studies for the doctorate. While working toward his master's degree, Frank had become interested in the neuropsychology of learning, and had gravitated to Karl Lashley at the University of Chicago. When Lashley moved to Harvard University, Frank followed, supplementing his meager stipend by various means, including singing in a choir. Frank was an earthy man, and it is not easy to imagine him as a choir "boy."

By the time he received his PhD in 1940, Frank was already Assistant Curator in the Department of Experimental Biology at the American Museum of Natural History. When that department was threatened with dismantlement, Frank proposed, successfully, that it be reorganized as the Department of Animal Behavior. In 1942, he became the department's first chairman, and it flourished with a group that came to include Lester Aronson, T. C. Schneirla, and, visiting occasionally, a precocious teenager named Daniel Lehrman. This group virtually founded a school of comparative psychology. Frank also recognized early on the potential contribution of European ethology to American comparative psychology, and he was instrumental in initiating and facilitating the cross-pollination of these two approaches to behavior (see, e.g., 1950, 1951, 1960).

B. D. Sachs's mailing address is: Department of Psychology, The University of Connecticut, Storrs, CT 06269-1020.
In 1946, Frank, clearly a rara avis, started his academic career at the level of Professor when he moved to Yale University's Psychology Department. He was named Sterling Professor in 1952, and stayed at Yale until 1957. During a year at the Center for Advanced Study in Behavioral Sciences at Stanford, Frank was offered a position by the Psychology Department at the University of California, Berkeley. Tempted by the less dogmatic intellectual climate of this department and the more benign atmospheric climate of northern California, Frank accepted the offer. In Berkeley, Frank and his graduate students and postdoctoral fellows thrived. Frank's education of his students was in large part a matter of setting an intellectual example with what Gordon Bermant aptly characterized as rigor illuminated by common sense, rather than constrained by the expectation of doctrinaire allegiance. His seminars were not occasions for passively receiving wisdom, but for being infected with Frank's enthusiasm for empirical research. Lively debate was spiced by Frank's ample wit and rapier-like turns of phrase, which could, with a stroke, deflate pomposity or uncover poor preparation.

Frank was an academic and political traditionalist, a conservative, potentially at odds with the student movements developing in Berkeley and elsewhere in the 1960s. But his politics was his and his students' theirs, and the divergent views did not engender hostility or disrespect. How could we be disrespectful of a professor who was not only our clear intellectual superior, but who, on the rare occasions he elected to, would roll up his sleeves past his tattoo and proceed to beat the pants off us at pool or shuffleboard or darts, even while drinking us under the table? (It should be remembered that many generations of students considered all these abilities inestimable assets.) There was some discussion among us about Frank's declaration that he "would never have ovaries in his lab," perhaps because of the colorful way he expressed his bias, rather than because of a strong feminist bent among that crop of students. At that time he, like many of his colleagues, had not had any women as graduate students in his lab, and it would be scant exaggeration to say that he 
was an academic and intellectual misogynist. However, Frank's attitudes, like the times, were achanging, and in subsequent years he not only had women earn the $\mathrm{PhD}$ with him, but he actively encouraged them and other women in the field with conversations and correspondence that affirmed his appreciation of-often excitement about-their contributions to science.

Frank Beach's 50 years of scientific contributions to psychology and related sciences were multifaceted. He began as a neuropsychologist-. "The Neural Basis of Innate Behavior" (1937) was the title of his dissertation, which was also his first scientific publication. This research on cortical involvement in the maternal behavior of rats marked the beginning of his lifelong interest in understanding the physiological basis of behavior, and of species-typical, instinctive behavior in particular. Although Frank published several important papers dealing with agonistic behavior and play, his major behavioral focus was on sexual behavior, and it is here that his influence is most visible. His manifold contributions to conceptual development and methodology, buttressed by a wealth of data from descriptive and analytic studies, were fundamental to sex research on animals and humans, and will be for many years to come.

Frank's first book, Hormones and Behavior (1948), was the first compendium of research on the title subject. The volume emerged from a lecture and term paper he had prepared for a course in endocrinology that he had audited at New York University while already a curator at the American Museum of Natural History, and it reflected the shift in Frank's primary interest from the neural to the hormonal basis of behavior. It was to this area that he devoted most of his research for the rest of his life. Charles Phoenix once noted that if William C. Young brought behavior to endocrinology, Frank Beach brought endocrinology to behavior. The result was the discipline of "behavioral endocrinology." By 1969, the field was large enough to warrant its own journal, and Frank (with Julian Davidson and Richard Whalen) launched Hormones and Behavior. Having established the field, Frank defined it (1975) and wrote a brief history of it (1981).

Frank's early and enduring interest in instinctive behavior inevitably involved him in nature-nurture questions. His classic critique of the early ethological approach to this problem is the oft-reprinted "The De-scent of Instinct"' (1955). (The editors of Psychological Review unfortunately lost Frank's jocular intent with the title when they deleted the hyphen.) His review (with Julian Jaynes) of the "Effects of Early Experience upon the Behavior of Animals"' (1954) provided a valuable and influential framework in this expanding area of research. Of particular relevance to this special issue of Psychobiology is that much of Frank's research and thinking on problems of development concerned the origins of sex differences and similarities in behavior. His review of sexual differentiation, "Hormonal Factors ... in the Ramstergig and Related Species"' (1971), was an eloquent, if not entirely fair, "lengthy diatribe" (his characterization) against what he viewed as the premature conclusion that central neural factors were necessarily primary to observed differences in sexual behavior. (In the meantime, researchsee, e.g., Rand \& Breedlove, this issue-has confirmed that sex differences in experience and in peripheral anatomy can indeed shape central neural differences.) In recent years, Frank again labored to develop an alternative to the organizational/activational framework, a dichotomy that he felt had too long constrained thinking about the mediation of hormonal effects at different developmental stages. One fruit of that labor was yet another renewal of his research grant from the National Institutes of Health, a rare award for emeritus scientists.

Frank's famous "The Snark was a Boojum" (1950) was a critique of American comparative psychology's preoccupation with rats. The paper exemplified Frank's personal identification with comparative psychology, and his enduring concern that psychology should be comparative. The comparative perspective illuminated his work, and he published experimental studies of cats, hamsters, pigeons, chinchilla, quail, guinea pigs, and dogs, as well as, of course, rats. Frank had special zest and affection for his work on dogs, well captured in his delightful "Locks and Beagles" (1969). In recent years, he was actively involved in the research program on spotted hyenas being directed by Stephen Glickman, and Frank had completed a draft of a paper on play in this species shortly before he died. Despite his focus on the behavior of animals, Frank never lost sight of human behavior. Crossspecies and cross-cultural comparisons were the paradigm of Patterns of Sexual Behavior (1952, with the anthropologist C. S. Ford). This volume was followed by many papers devoted to human behavior and by his editing of Human Sexuality in Four Perspectives (1977), namely, developmental, sociological, physiological, and evolutionary. (Of course, Frank had also applied each of these perspectives to nonhuman behavior.) In later years, Frank (1984) rejected the central thesis of "The Snark ..." -that is, that the measure of a comparative science is how many species are investigated-and he spoke of the desirability, if comparative psychology was to remain a viable discipline, of reviving the mental life of animals as a subject of research. However, Frank had no patience for those who wrung their hands over the real or imagined death of comparative psychology.

Frank was very important to his colleagues, his students, and his family, but he was rarely self-important. When he was invited to write an autobiographical memoir for Pioneers in Neuroendocrinology (1978), he titled it, "Confessions of an Imposter," reflecting a modesty about his credentials as a neuroendocrinologist, but probably also an unfortunate uncertainty about the worth of his contributions to science. Few shared his doubts, and he was honored early and often for his substantial and diverse contributions. Frank was elected president of the American Psychological Association's Division of Experimental Psychology, and president of both the Eastern Psychological Association and the Western Psychological 
Association. He was a member of the National Academy of Sciences, fellow of the American Academy of Arts and Sciences, and a recipient of the APA Distinguished Scientific Contribution Award and the Society of Experimental Psychologists' Warren Medal for excellence in experimentation. Frank's renown as a teacher was rewarded in 1985 with the APA's Gold Medal for distinguished teaching in comparative psychology. He received honorary doctorates from McGill University and Williams College, and just a month or so before he died, Frank went home again to Emporia, Kansas, to receive an honorary Doctor of Humane Letters degree from his alma mater.

Frank retired formally in 1978, but in the years since then he continued to work, mainly at home in the East Bay hills. There, too, he and Noel, his devoted and gracious wife, welcomed visitors with a relaxed hospitality that made one feel very much at home. Commonly the visit included a trip down to Frank's study, which, like most of the house, commanded a magnificent view from the East Bay hills south to Oakland and west to San Francisco. There Frank enjoyed bouncing off visitors ideas from his most recent projects. One of these projects harkened back to an early stage of his career. Frank had recently audited an endocrinology course at Berkeley, and he was distressed by the short shrift given to environmentorganism-hormone interactions in that course and most endocrinology texts. As a result, Frank undertook, as a "'term paper," to synthesize the ecological aspects of behavioral endocrinology. It is clear that Frank never quite retired. Bouts of cardiovascular problems slowed him in recent years to a pace that much younger scholars might settle for. He continued to think creatively, to write with clarity and wit, and to inspire. He will be remembered with respect and affection by several generations of students and colleagues, and our science will be the better for his influence.

\section{REFERENCES}

BeACH, F. A. (1937). The neural basis of innate behavior: I. Effects of cortical lesions upon the maternal behavior pattern in the rat. Journal of Comparative Psychology, 24, 393-436.

BEACH, F. A. (1948). Hormones and behavior. New York: Paul B. Hoeber.

Beach, F. A. (1950). The Snark was a Boojum. American Psychologist, 5, 115-124.

BEACH, F. A. (1951). Instinctive behavior: Reproductive activities. In S. S. Stevens (Ed.), Handbook of experimental psychology (pp. 387434). New York: John Wiley.

BeACH, F. A. (1955). The descent of instinct. Psychological Review, 62, 401-410.

BEACH, F. A. (1960). Experimental investigations of species-specific behavior. American Psychologist, 15, 1-19.

BeACH, F. A. (1969). Locks and beagles. American Psychologist, 24, 971-989.

BEACH, F. A. (1971). Hormonal factors controlling the differentiation, development, and display of copulatory behavior in the ramstergig and related species. In E. Tobach, L. R. Aronson, \& E. Shaw (Eds.), The biopsychology of development (pp. 249-296). New York: Academic Press.

BEACH, F. A. (1974). Frank A. Beach. In G. Lindzey (Ed.), A history of psychology in autobiography: Vol. 6 (pp. 31-58). Englewood Cliffs, NJ: Prentice Hall.

BEACH, F. A. (1975). Behavioral endocrinology: An emerging discipline. American Scientist, 63, 178-187.

BEACH, F. A. (Ed.). (1977). Human sexuality in four perspectives. Baltimore: Johns Hopkins University Press.

BEACH, F. A. (1978). Confessions of an impostor. In J. Meites, B. T. Donovan, \& S. M. McCann (Eds.), Pioneers in neuroendocrinology: Vol. 2 (pp. 19-35). New York: Plenum Press.

BEACH, F. A. (1981). Historical origins of modern research on hormones and behavior. Hormones \& Behavior, 15, 325-376.

BeaCh, F. A. (1984). Let's bury the Snark. Comparative Psychology Newsletter, 4(2), 1-3.

BEACH, F. A., \& JAYNES, J. (1954). Effects of early experience upon the behavior of animals. Psychological Bulletin, 51, 239-263.

FORD, C. S., \& BEACH, F. A. (1952). Patterns of sexual behavior. New York: Harper \& Hoeber.

(Manuscript received August 17, 1988.) 